\title{
Hormonal Physiological Changes of Testis Resulting From Exposure to Vinyl Cyanide and the Possible Protective Role of $\beta$-cryptoxanthin in Male Rat
}

\author{
Nura I. Al-Zail \\ Department of Zoology, Faculty of Science, Omar Al-Mukhtar University, Al-Bayda, Libya.
}

Received:29 March 2021 / Accepted: 15 June 2021

Doi: https://doi.org/10.54172/mjsc.v36i2.58

\begin{abstract}
Vinyl cyanide (VCN) is an aliphatic nitrile product which is extensively used in various synthetic chemical industries. VCN is known to exert toxic actions to human beings as well as experimental animals. The present study was designed to examine the ability of $\beta$-cryptoxanthin, a naturally occurring antioxidant, to attenuate $\mathrm{VCN}$-induced testicular toxicity in adult albino rats.

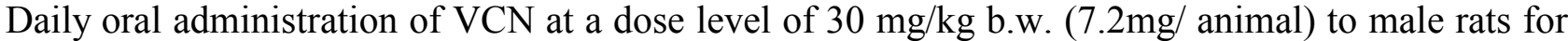
a period of 5 days significantly reduced the levels of serum testosterone (T), androsterone, folliclestimulating hormone (FSH) and luteinizing hormone ( $\mathrm{LH})$ which indicates injury to the testis function. Compared to VCN-treated animals, pretreatment with $\beta$-cryptoxanthin and its coadministration with VCN once daily at a dose of $40 \mathrm{mg} / \mathrm{kg}$ b.w. (9.6mg/ animal) for 30 days induced a remarkable degree of improvement in the levels of endocrine parameters including T, androsterone, FSH and LH. In conclusion, the present results clearly demonstrate the protective role of $\beta$-cryptoxanthin against $\mathrm{VCN}$-induced physiological changes in the testis of rats.
\end{abstract}

Keywords: Vinyl cyanide; $\beta$-cryptoxanthin; Hormones; Testes; Rats.

\section{INTRODUCTION}

Vinyl cyanide $\left(\mathrm{C}_{3} \mathrm{H}_{3} \mathrm{~N}, \mathrm{VCN}\right)$, also known as acrylonitrile, a highly reactive compound having an active vinyle and cyanide groups, which has been widely used in industry for production of plastics, elastomers, and synthetic fibres and as an intermediate in the synthesis of industrial chemicals and pharmaceuticals (Humans, 1979). It is also used in the manufacture of soft prosthesis material (Parker \& Braden, 1990), coating membranes for Langerhans islets implants (Kessler et al., 1992) and high permeable dialysis tubing (Ward et al., 1993).

Human exposure to VCN could potentially occur during the manufacturing process, end product usage and transportation. Further, such exposure can also be possible in the general population through cigarette smoke and via contamination of drinking water
(Byrd et al., 1990). VCN demonstrated acute toxicity in testes of rats, mice, rabbits and guinea pigs having a high acute toxicity result from inhalation, and a high to extreme acute toxicity result from oral or dermal exposure (Mathieu-Denoncourt et al., 2015; Thier et al., 2000). VCN is teratogenic in laboratory animals (rat and hamster) at high doses when maternal toxicity has been already manifested. VCN has been demonstrated to induce embryotoxic effects in rat (Saillenfait \& Sabate, 2000).

VCN-induced embryotoxic and teratogenic effects have also been found in VCN-exposed workers (Wu et al., 1995). According to environmental teratologic epidemiological study in inhabitants living in the surrounding region of an acrylonitrile factory, three congenital abnormalities (pectus excavatum, undescended testis and clubfoot) in 46,326 infants showed significant time-space clusters in the

*Corresponding Author: Nura I. Al-Zail nurazail1982@gmail.com, Department of Zoology, Faculty of Science, Omar Al-Mukhtar University, ElBeida, Libya. 
study region. There was a decrease in risk of undescended testis with increasing distance from the acrylonitrile factory (Czeizel et al., 1999). Therefore, women not professionally exposed would appear to be at risk of teratogenic effects due to VCN toxicity.

VCN is rapidly absorbed and distributed to all major tissues in animals. Previous studies with 14C have shown that VCN covalently binds to thiol group of proteins (Ahmed et al., 1982) and tissue macromolecules and nucleic acids (Pilon et al., 1988). Therefore, estimation of free radical generation and antioxidant defence has become an important aspect of investigation in mammals. Carotenoids ( $\beta$-cryptoxanthin or what is known as $\beta$-carotene) are naturally occurring antioxidants that play an important role in animal health by inactivating harmful free radicals produced through normal cellular activity and from various stressors. The antioxidant function of these micro-nutrients could, at least in part, enhance the immunity by maintaining the functional and structural integrity of important immune cells (Chew, 1995; ElDemerdash et al., 2004).

$\beta$-cryptoxanthin, aside from being a major source of vitamin A (retinol), an essential vitamin for spermatogenesis to proceed, has been reported to be a potent free radical quencher, singlet oxygen scavenger and lipid antioxidant (Burton, 1989; El - Missiry \& Shalaby, 2000) focused on the ability of $\beta$ cryptoxanthin to function as a chain-breaking antioxidant in a lipid environment at physiological oxygen partial pressures that are considered most likely in mammalian cells. Therefore, the aim of the current study was to investigate the efficacy of $\beta$-cryptoxanthine on VCN-induced functional and structural alterations related to oxidative stress in the testes of rats.

\section{MATERIALS AND METHODS}

Chemicals: Vinyl cyanide (VCN) and $\beta$ cryptoxanthin were obtained from Sigma-
Aldrich Chemical Company (St. Louis, MO, USA) and given by oral gavage at dose of 30 $\mathrm{mg} / \mathrm{kg}$ b.w. (Takano et al., 2010) and $40 \mathrm{mg} / \mathrm{kg}$ b.w. (Sadir et al., 2007), respectively. All other chemicals and solvent used were of highest available commercial grade.

Experimental animals: Fourty male SpragueDawely rats, each weighing $240 \pm 10 \mathrm{~g}$. The animals were housed in stainless steel cages after grouping in batches of five animals under standard animal house conditions of relative humidity $(55 \pm 5 \%)$, temperature $\left(25 \pm 2{ }^{\circ} \mathrm{C}\right)$ and a $12 \mathrm{hr}$ light/12 hr dark cycle. Rats were allowed free access to standard commercial feed and tap water and were acclimatized to laboratory conditions for a period of one week before the onset of experimentation.

Experimental protocol: Animals were allocated to four groups each of ten rats as follows: Group I: (Control) pre-treated with corn oil (2 $\mathrm{ml} / \mathrm{kg}$ b.w.) once daily for 25 days and treatment continued with distilled water $(2 \mathrm{ml} / \mathrm{kg}$ b.w.) once daily for additional 5 days i.e. from day 26 to day 30 of the experimental period of 30 days.

Group II: (VCN group) pre-treated with corn oil ( $2 \mathrm{ml} / \mathrm{kg}$ b.w.) once daily for 25 days and treatment continued with VCN in a dose of 30 $\mathrm{mg}$ in $2 \mathrm{ml}$ distilled water per $\mathrm{kg}$ b.w. $(7.2 \mathrm{mg} /$ animal) once daily for additional 5 days.

Group III: ( $\beta$-cryptoxanthin group) pre-treated with $\beta$-cryptoxanthin in dose of $40 \mathrm{mg}$ in $2 \mathrm{ml}$ corn oil per kg b.w. (9.6mg/ animal) once daily for 25 days and treatment continued with distilled water $(2 \mathrm{ml} / \mathrm{kg}$ b.w.) for additional 5 days.

Group IV: ( $\beta$-cryptoxanthin and VCN group) pre-treated with $\beta$-cryptoxanthin $(40 \mathrm{mg} / \mathrm{kg}$ b.w.) for 25 days and treatment continued with VCN (30 mg/kg b.w) for additional 5 days.

At the end of the experimental period, the tested animal groups were sacrificed after $24 \mathrm{~h}$ of the last dose of different administrations and (C) 2021 The Author(s). This open access article is distributed under a CC BY-NC 4.0 license. ISSN: online 2617-2186 print 2617-2178 
their blood were collected by carotid bleeding in centrifuge tubes, serum was obtained from the blood after centrifugation at $3000 \mathrm{rpm}$ for $10 \mathrm{~min}$.

Methods of analysis: Determination of luteinizing ( $\mathrm{LH})$, testosterone ( $\mathrm{T}$ ) and androsterone hormones in serum were carried out according to the method of (Jaffe \& Behrman, 1974) and follicle stimulating hormone (FSH) was measured by radioimunoassay (RIA) using the method of (Rose, 1998).

Statistical analysis: Statistical analyses of the resulted data were done using In-Stat version 2.0 (Graph Pad, ISI, Philadelphia, PA, USA, 1993) computer software. The results were expressed as means $( \pm \mathrm{SE})$. Multiple comparisons were done using one-way ANOVA followed by Tukey-Kramer as a post-ANOVA test. Statistical significance was accepted at $\mathrm{P}<0.001$,
$\mathrm{P}<0.01, \mathrm{P}<0.05$.

\section{RESULTS AND DISCUSSION}

Analysis studies: Data listed in Table 1 show that treatment with VCN caused a significant $(\mathrm{P}<0.001)$ decrease in the levels of $\mathrm{T}$, androsterone, FSH and $\mathrm{LH}$, respectively as compared to the corresponding control group. Pre-and co-administration of $\beta$-cryptoxanthin to $\mathrm{VCN}$ challenged rats significantly improved $(\mathrm{P}<0.001)$ the levels of these hormones as compared to VCN-treated group.

From these results it is clear that vinyl cyanide has been demonstrated to induce male reproductive toxicity in laboratory animals (Ahmed et al., 1992; Liu et al., 2004) and also in VCNexposed workers (Xu et al., 2003).

Table:(1). The effect of vinyl cyanide (30 mg/kg b.w.) and/or $\beta$-cryptoxanthin (40 mg/kg b.w.) on serum testosterone, androsterone, FSH and LH of male albino rats.

\begin{tabular}{|c|c|c|c|c|}
\hline $\begin{array}{l}\text { Groupe } \\
\text { Hormone }\end{array}$ & Control & $\mathrm{VCN}$ & קcryptoxanthin & $\beta$ cryptoxanthin $+\mathrm{VCN}$ \\
\hline $\begin{array}{l}\text { Testosterone } \\
\mathrm{ng} / \mathrm{ml}\end{array}$ & $7.05 \pm 0.04$ & $\begin{array}{l}3.00 \pm 0.03 \\
(-57.45 \%) \\
a^{* *}\end{array}$ & $\begin{array}{l}7.63 \pm 0.09 \\
(8.23 \%) \\
a * * b * *\end{array}$ & $\begin{array}{l}4.62 \pm 0.16 \\
(-34.47 \%) \\
a * * b * c * *\end{array}$ \\
\hline $\begin{array}{l}\text { Androsterone } \\
\mathrm{pg} / \mathrm{ml}\end{array}$ & $49.41 \pm 0.29$ & $\begin{array}{l}30.41 \pm 0.22 \\
(-38.45 \%) \\
a^{* *}\end{array}$ & $\begin{array}{l}52.40 \pm 0.27 \\
(6.05 \%) \\
a^{* * b * *}\end{array}$ & $\begin{array}{l}41.61 \pm 0.83 \\
(-15.79 \%) \\
a^{* * b * *} \mathrm{c}^{* *}\end{array}$ \\
\hline $\begin{array}{l}\mathrm{FSH} \\
\mathrm{pg} / \mathrm{ml}\end{array}$ & $10.64 \pm 0.12$ & $\begin{array}{l}4.09 \pm 0.26 \\
(-61.65 \%) \\
a^{* *}\end{array}$ & $\begin{array}{l}12.61 \pm 0.16 \\
(18.52 \%) \\
a^{* * b} b^{* *}\end{array}$ & $\begin{array}{l}8.32 \pm 0.22 \\
(-21.80 \%) \\
a^{* * b * *} c^{* *}\end{array}$ \\
\hline $\begin{array}{l}\mathrm{LH} \\
\mathrm{mIU} / \mathrm{ml}\end{array}$ & $8.96 \pm 0.10$ & $\begin{array}{l}4.51 \pm 0.06 \\
(-49.67 \%) \\
a^{* *}\end{array}$ & $\begin{array}{l}9.26 \pm 0.15 \\
(3.35 \%) \\
b * *\end{array}$ & $\begin{array}{l}7.48 \pm 0.12 \\
(-16.52 \%) \\
a * * b * * * *\end{array}$ \\
\hline $\begin{array}{l}\text { - Data are expressed } \\
\text { - Values between pa } \\
\text { a: Significant change } \\
\text { b: Significant change } \\
\text { c: Significant change } \\
\text { **Very high signific }\end{array}$ & $\begin{array}{l}=10 \text { in each grou } \\
\text { difference } \% \text { of ea } \\
\text { respect to control } \\
\text { respect to VCN-gr } \\
\text { respect to } \beta \text {-crypto } \\
\text { at } P<0.001 \text {. }\end{array}$ & $\begin{array}{l}\text { eter with respect } \\
\text { group. }\end{array}$ & value. & \\
\hline
\end{tabular}

Whole body autoradiography and toxicokinetic studies showed that the brain is a target organ for VCN toxicity (Ahmed et al., 1982). (McLachlan et al., 2002)reported that endocrine support is essential for normal spermato genesis and disturbance can lead to altered spermatogenesis in both humans and rodents. Therefore, the decrease in the levels of serum T, androsterone, FSH and LH could be explained in the current study. The present results are in accordance with the study of (Ivănescu et (C) 2021 The Author(s). This open access article is distributed under a CC BY-NC 4.0 license. ISSN: online 2617-2186 print 2617-2178 
al., 1990) who reported that VCN decreases testosterone synthesis and/or secretion in humans. In this study, the observed decrease in the levels of $\mathrm{T}$ and androsterone following VCN administration may be attributed to the increase in oxidative stress. This finding is consistent with that of (Diemer et al., 2003; Mathieu-Denoncourt et al., 2015) who showed that $\mathrm{H}_{2} \mathrm{O}_{2}$ is a potent oxidant that could inhibit steroidogenesis (reduce testosterone synthesis) in Leydig cells. Similarly, (Yang et al., 2005) reported that serum $\mathrm{T}$ level and Leydig cell viability were decreased in rats treated with the structurally similar vinyl monomer, Vinyl cyanide (VCA). Their interpretation is that the decreased viability of Leydig cells caused by VCA treatment lowered testestrone level, which in turn, reduced spermatogenesis in the rat testes. Furthermore, the results of (ElYamany, 2009) showed a significant decline in serum levels of T, FSH, LH and prolacting (PRL) of rats fallowing VCA administration.

The author attributed the decline of T, FSH, LH and PRL levels to the dysfunction of pituitary gland and also demonstrated that VCA affects the testes directly and/or indirectly through its effect on pituitary gland and decreases the secretion of FSH and LH. Also, the present results are in accordance with the study of (Gunnarsson et al., 2003) who found that cadmium caused a decrease in $\mathrm{T}$ production through the decrease in LH receptor messenger ribonucleic acid (mRNA) levels as well as cyclic adenosine monophosphate (cAMP) levesl in rats.

To protect spermatogenesis from toxicant exposure, many clinical and experimental trials of antioxidant agents have been attempted. Carotenoids as potential antioxidant are well known as highly efficient scavengers of singlet molecular oxygen (1O2), and other excited species. The present study indicates the beneficial effects of $\beta$-cryptoxanthin against vinyl cyanide induced testicular toxicity. $\beta$-cryptoxanthin treatment improved the levels of endocrine parameters including $\mathrm{T}$, androsterone, FSH and LH. These results are in agreement with those (C) 2021 The Author(s). This open access article is distributed under a CC BY-NC 4.0 license. ISSN: online 2617-2186 print 2617-2178 obtained by (Livera et al., 2002) who found that in adult rats, retinoids increased basal testosterone secretion in Leydig cell primary cultures. Also, (Hanukoglu, 2006) reported that the antioxidant enzyme activities superoxide dismutase, catalase, and glutathione peroxidase are parallel steroidogenesis and the antioxidant $\beta$-cryptoxanthin exerted a protective role on Leydig cell steroidogenesis to produce testosterone; thus it stimulates the development of reproductive organs through the growth of Leydig and Sertoli cells and the promotion of spermatogenesis. Also, (Silva et al., 2001) suggested that pretreatment with another carotenoid, bixin reduced the total number of chromosome aberrations and inhibited the increase in lipid peroxidation induced by cisplatin. Furthermore, (Gupta \& Kumar, 2002) elucidated that the effect of oral lycopene, a naturally occurring carotenoid in tomatoes, therapy in men with idiopathic infertility and found improvement in male infertility and especially in sperm characteristics.

A rational mechanism for the protective effects of $\beta$-cryptoxanthin could be the potential antioxidant activity. Because $\beta$-cryptoxanthin is a lipophilic substance, it exerts its action in hydrophobic environment such as the lipid core of membranes. Thus, it is anticipated that natural $\beta$-cryptoxanthin, a chain breaking antioxidants, can contribute to protecting cell membranes from lipid peroxidation (Krinsky, 1998). $\beta$ cryptoxanthin can function as an effective antioxidant not only against singlet oxygen but also against lipid peroxidation and the highly destructive, hydroxyl radical $\mathrm{OH} \bullet$ that is implicated in many diseases such as cancer and heart disease (O'neill \& Thurnham, 1998).

\section{CONCLUSION}

In conclusion, this study clearly demonstrated the potential antioxidant benefit of $\beta$ cryptoxanthin in managing $\mathrm{VCN}$-induced physiological changes in the testes of rats.

\section{REFERENCES}


Ahmed, A. E., Abdel - Rahman, S. Z., \& Nour Deen, A. M. A. (1992). Acrylonitrile interaction with testicular DNA in rats. Journal of biochemical toxicology, 7(1), 5-11.

Ahmed, A. E., Farooqui, M. Y., Upreti, R. K., \& El-Shabrawy, O. (1982). Distribution and covalent interactions of [1-14C] acrylonitrile in the rat. Toxicology, 23(2-3), 159-175.

Burton, G. W. (1989). Antioxidant action of carotenoids. The Journal of Nutrition, 119(1), 109-111.

Byrd, G., Fowler, K., Hicks, R., Lovette, M., \& Borgerding, M. (1990). Isotope dilution gas chromatography-mass spectrometry in the determination of benzene, toluene, styrene and acrylonitrile in mainstream cigarette smoke. Journal of Chromatography A, 503, 359-368.

Chew, B. P. (1995). Antioxidant vitamins affect food animal immunity and health. The Journal of Nutrition, 125(suppl_6), 1804S-1808S.

Czeizel, A. E., Hegedüs, S., \& Tímár, L. (1999). Congenital abnormalities and indicators of germinal mutations in the vicinity of an acrylonitrile producing factory. Mutation Research/Fundamental and Molecular Mechanisms of Mutagenesis, 427(2), 105-123.

Diemer, T., Allen, J. A., Hales, K. H., \& Hales, D. B. (2003). Reactive oxygen disrupts mitochondria in MA-10 tumor Leydig cells and inhibits steroidogenic acute regulatory (StAR) protein and steroidogenesis. Endocrinology, 144(7), 2882-2891.
El-Demerdash, F. M., Yousef, M. I., Kedwany, F. S., \& Baghdadi, H. H. (2004). Cadmium-induced changes in lipid peroxidation, blood hematology, biochemical parameters and semen quality of male rats: protective role of vitamin $\mathrm{E}$ and $\beta$-carotene. Food and chemical toxicology, 42(10), 15631571.

El-Yamany, N. A. (2009). Effect of acrylamide toxicity on reproductive hormones of adult male albino rats and the ameliorative role of vitamin E. Egypt $J$. Zool, 52, 205-220.

El - Missiry, M., \& Shalaby, F. (2000). Role of $\beta$ - carotene in ameliorating the cadmium - induced oxidative stress in rat brain and testis. Journal of biochemical and molecular toxicology, 14(5), 238-243.

Gunnarsson, D., Nordberg, G., Lundgren, P., \& Selstam, G. (2003). Cadmium-induced decrement of the LH receptor expression and cAMP levels in the testis of rats. Toxicology, 183(1-3), 5763.

Gupta, N. P., \& Kumar, R. (2002). Lycopene therapy in idiopathic male infertility-a preliminary report. International Urology and Nephrology, 34(3), 369372.

Hanukoglu, I. (2006). Antioxidant protective mechanisms against reactive oxygen species (ROS) generated by mitochondrial P450 systems in steroidogenic cells. Drug metabolism reviews, 38(1-2), 171-196.

Humans, I. W. G. o. t. E. o. t. C. R. o. C. t. (1979). IARC Monographs on the Evaluation of the Carcinogenic Risk of Chemicals to Humans (Vol. 19). IARC. 
Ivănescu, M., Berinde, M., \& Simionescu, L. (1990). Testosterone in sera of workers exposed to acrylonitrile. Endocrinologie, 28(3-4), 187-192.

Jaffe, B., \& Behrman, N. (1974). Methods of normone radio immuno assay Academic pross.

Kessler, L., Aprahamian, M., Keipes, M., Damge, C., Pinget, M., \& Poinsot, D. (1992). Diffusion properties of an artificial membrane used for Langerhans islets encapsulation: an in vitro test. Biomaterials, 13(1), 44-49.

Krinsky, N. I. (1998). The Antioxidant and Biological Properties of the Carotenoids a. Annals of the New York Academy of Sciences, 854(1), 443-447.

Liu, X., Xiao, W., Wang, Z., \& Lian, S. (2004). Effect of acrylonitrile on the spermatogenesis in mice. Wei sheng yan jiu= Journal of hygiene research, 33(3), 345-347.

Livera, G., Rouiller-Fabre, V., Pairault, C., Levacher, C., \& Habert, R. (2002). Regulation and perturbation of testicular functions by vitamin A. REPRODUCTION-CAMBRIDGE-, 124(2), 173-180.

Mathieu-Denoncourt, J., Wallace, S. J., de Solla, S. R., \& Langlois, V. S. (2015). Plasticizer endocrine disruption: Highlighting developmental and reproductive effects in mammals and non-mammalian aquatic species. General and comparative endocrinology, 219, 74-88.

McLachlan, R. I., O'Donnell, L., Meachem, S. J., Stanton, P., De Kretser, D., Pratis, K., \& Robertson, D. (2002). Identification of specific sites of hormonal regulation in spermatogenesis in rats, monkeys, and man. Recent progress in hormone research, 57(1), 149-179.

O'neill, M., \& Thurnham, D. (1998). Intestinal absorption of $\beta$-carotene, lycopene and lutein in men and women following a standard meal: response curves in the triacylglycerol-rich lipoprotein fraction. British Journal of Nutrition, 79(2), 149159.

Parker, S., \& Braden, M. (1990). Soft prosthesis materials based on powdered elastomers. Biomaterials, 11(7), 482490.

Pilon, D., Roberts, A. E., \& Rickert, D. E. (1988). Effect of glutathione depletion on the uptake of acrylonitrile vapors and on its irreversible association with tissue macromolecules. Toxicology and applied pharmacology, 95(2), 265-278.

Rose, M. P. (1998). Follicle stimulating hormone: international standards and reference preparations for the calibration of immunoassays and bioassays. Clinica chimica acta, 273(2), 103-117.

Sadir, S., Deveci, S., Korkmaz, A., \& Oter, S. (2007). Alpha - tocopherol, beta carotene and melatonin administration protects cyclophosphamide - induced oxidative damage to bladder tissue in rats. Cell Biochemistry and Function: Cellular biochemistry and its modulation by active agents or disease, 25(5), 521-526.

Saillenfait, A., \& Sabate, J. (2000). Comparative developmental toxicities of aliphatic nitriles: in vivo and in vitro observations. Toxicology and applied pharmacology, 163(2), 149-163. 
Silva, C. R., Antunes, L. M. G., \& Maria de Lourdes, P. B. (2001). Antioxidant action of bixin against cisplatin-induced chromosome aberrations and lipid peroxidation in rats. Pharmacological Research, 43(6), 561-566.

Takano, R., Murayama, N., Horiuchi, K., Kitajima, M., Kumamoto, M., Shono, F., \& Yamazaki, H. (2010). Blood concentrations of acrylonitrile in humans after oral administration extrapolated from in vivo rat pharmacokinetics, in vitro human metabolism, and physiologically based pharmacokinetic modeling. Regulatory toxicology and pharmacology, 58(2), 252-258.

Thier, R., Lewalter, J., \& Bolt, H. M. (2000). Species differences in acrylonitrile metabolism and toxicity between experimental animals and humans based on observations in human accidental poisonings. Archives of toxicology, 74(4-5), 184-189.

Ward, R., Schaefer, R., Falkenhagen, D., Joshua, M., Heidland, A., Klinkmann, H., \& Gurland, H. (1993). Biocompatibility of a new highpermeability modified cellulose membrane for haemodialysis. Nephrology Dialysis Transplantation, 8(1), 47-53.

Wu, W., Su, J., \& Huang, M. (1995). An epidemiological study on reproductive effects in female workers exposed to acrylonitrile. Zhonghua yu Fang yi xue za zhi [Chinese Journal of Preventive Medicine], 29(2), 83-85.

Xu, D.-X., Shen, H.-M., Zhu, Q.-X., Chua, L., Wang, Q.-N., Chia, S.-E., \& Ong, C.-N. (2003). The associations among semen quality, oxidative DNA damage in human spermatozoa and concentrations of cadmium, lead and selenium in seminal plasma. Mutation Research/Genetic Toxicology and Environmental Mutagenesis, 534(1-2), 155-163.

Yang, H.-J., Lee, S.-H., Jin, Y., Choi, J.-H., Han, D.-U., Chae, C., Lee, M.-H., \& Han, C.-H. (2005). Toxicological effects of acrylamide on rat testicular gene expression profile. Reproductive Toxicology, 19(4), 527-534. 


\title{
التغيرات الفسيولوجية الهرمونية للخصية الناتجة عن التعرض لسيانيد الفينيل والدور الوقائي المحتمل للبيتاكريبتوزانثين في ذكور الجرذان
}

\author{
نوره إبراهيم الزاعل \\ قسم علم الحيوان، كلية العلوم، جامعة عمر الدختار، البيضاء - لبييا.
}

تاريخ الاستلام: 29 مارس 2021 / تاريخ القبول: 15 يونيو 2021 النان https://doi.org/10.54172/mjsc.v36i2.58:Doi

المستخلص: سيانيد الفينيل منتج أليفاتي بستخدم على نطاق واسع في مختلف الصناعات الكيميائية الاصطناعية، ومن المعروف أن سيانيد الفينيل له تأثيرات سامة على البشر ، وكذلك حيوانات التجارب. وقد صُمدت هذه الدراسة لفحص قدرة بيتاكريبتوزانثين،

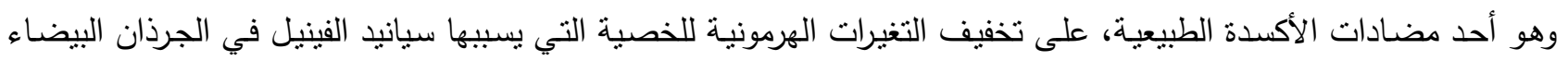

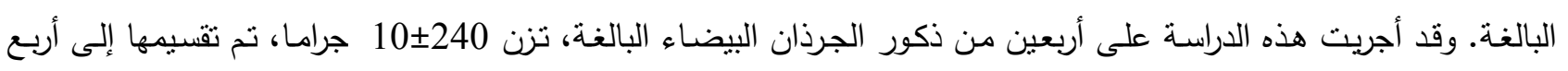

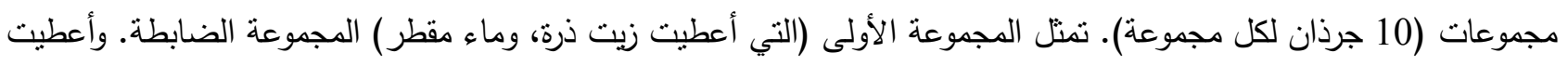

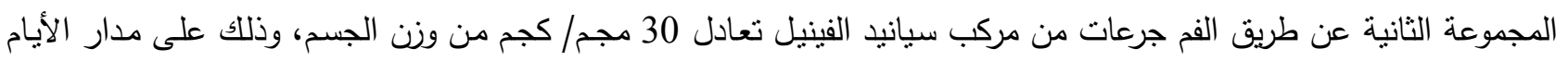

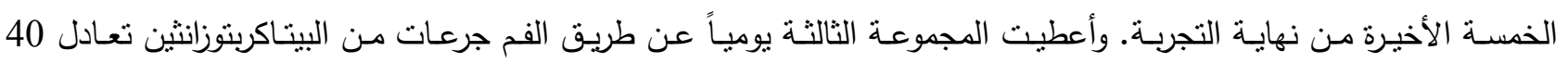

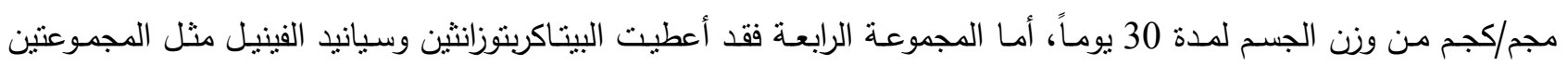

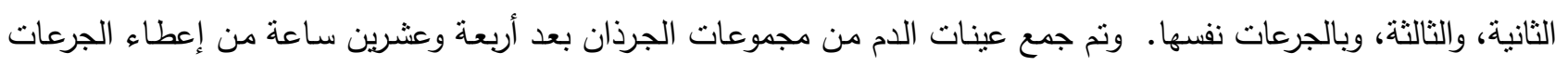

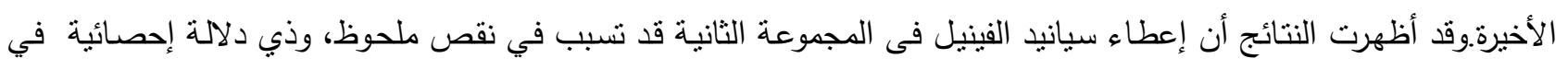

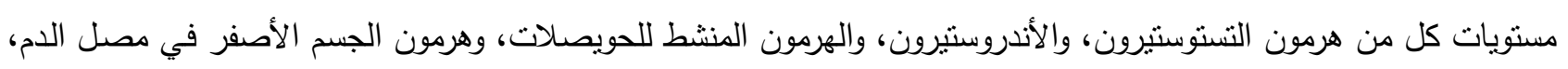

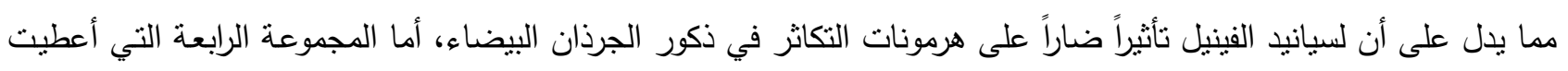

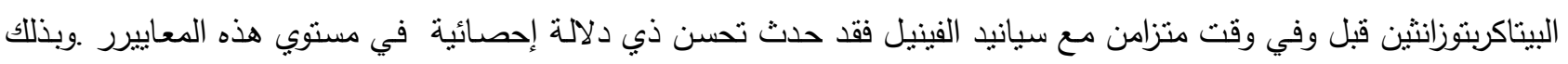

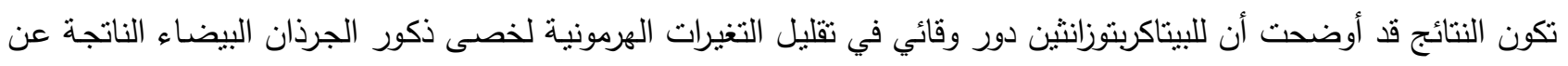
المعاملة بسيانيد الفينيل.

الكلمات المفتاحية: سيانيد الفينيل، بيتاكربتوزانثين، هرمونات، خصى، جرذان. 